\title{
Screening of the matrix metalloproteinase inhibitory activity on extracts from Cordyceps Neovolkiana DL0004 and Cordyceps Takaomontana DL0038A fungi
}

\author{
Nguyen Nguyet Hong ${ }^{1,4^{*}}$, Cao Ha Tim ${ }^{1}$, Nguyen Chi Dung ${ }^{2,3,4}$, Dinh Minh Hiep ${ }^{4}$, \\ Ngo Ke Suong ${ }^{3}$ \\ ${ }^{1}$ University of Science, Vietnam National University HCMC, Vietnam \\ ${ }^{2}$ Graduate University of Science and Technology, Vietnam Academy of Science and \\ Technology, Vietnam \\ ${ }^{3}$ Institute of Tropical Biology, Vietnam Academy of Science and Technology, Vietnam \\ ${ }^{4}$ Management Board of Agricultural Hi-Tech Park, Vietnam \\ *Corresponding author: hong.ahtp@gmail.com
}

\begin{tabular}{|c|c|}
\hline ARTICLE INFO & ABSTRACT \\
\hline $\begin{array}{l}\text { DOI: } 10.46223 / \text { HCMCOUJS. } \\
\text { tech.en.10.1.361.2020 }\end{array}$ & $\begin{array}{l}\text { Matrix Metalloproteinases (MMPs) are endopeptidases, they } \\
\text { are involved in tumor growth, and the processes of invasion and } \\
\text { metastasis. Cordyceps spp. were recorded to have the anticancer } \\
\text { potential. In previous studies, extracts from Cordyceps } \\
\text { neovolkiana strain DL0004 and Cordyceps takaomontana strain }\end{array}$ \\
\hline Received: October $1^{\text {st }}, 2019$ & DL0038A were capable of cytotoxic activity against MCF-7 and \\
\hline Revised: October $26^{\text {th }}, 2019$ & Jurkat cell lines. In this study, 26 extracts were prepared from \\
\hline Accepted: November $21^{\text {st }}, 2019$ & $\begin{array}{l}\text { biomasses and fruit bodies of } C \text {. neovolkiana DL0004 and } C \text {. } \\
\text { takaomontana DL0038A, then proceed to screen for MMP } \\
\text { inhibition assay by concentration ranges of } 2000 \mu \mathrm{g} / \mathrm{mL} \text {, } \\
200 \mu \mathrm{g} / \mathrm{mL}, 20 \mu \mathrm{g} / \mathrm{mL} \text {. The results showed that the CPS extract of }\end{array}$ \\
\hline Keywords: & $\begin{array}{l}\text { the fruit body of the } C \text {. neovolklana } \mathrm{DL0004} \text { had the highest } \\
\text { activity in MMP inhibition with } 84.27 \pm 4.59 \% \text { at } 2000 \mu \mathrm{g} / \mathrm{mL} \text {. }\end{array}$ \\
\hline $\begin{array}{l}\text { C. neovolkiana, C. } \\
\text { takaomontana, metastasis, } \\
\text { MMP }\end{array}$ & $\begin{array}{l}\text { The results were achievement for further studies of metastatic } \\
\text { inhibition activities of Cordyceps extracts. }\end{array}$ \\
\hline
\end{tabular}

\section{Introduction}

Matrix Metalloproteinases (MMPs) are zinc-binding endopeptidases to degrade extracellular matrix, for example, collagens, elastins, gelatins... (Chau, Rigg, \& Cunningham, 2003). It plays an important role in many physiological and pathological, overexpression of MMPs is involved in the invasion and metastasis of cancer (Robert et al., 2003).

Recently, several natural compounds have been used to support cancer treatment. Among them, research on the composition of Cordyceps fungi demonstrated the anti-tumor effect and the inhibitory effects on the production of inflammatory mediators (Hubbell, Requignot, Willis, Lee, \& Suhadolnik, 1985), anti-oxidation and stimulation of the immune 
system (Ha et al., 2006) ... Besides using the Cordyceps is isolated in Vietnam to studying antimetastasis limitedly. This study aimed to use the natural resource of Cordyceps collected in Vienam to evaluate the anti-cancer properties.

\section{Materials and methods}

\subsection{Materials}

Fungal samples: Cordyceps neovolkiana DL0004 (Le et al., 2010) and Cordyceps takaomontana DL0038A (Dinh et al., 2017) were collected and isolated from the forest by Dr. Truong in Lam Dong Province.

Collagenase from Clostridium histolyticum (MMP) were purchased from Sigma Aldrich, Inc., USA; The coomassive brilliant blue R250 dye (Merk, Germany) were dissolved $(0.2 \mathrm{w} / \mathrm{v}$ in $40 \%$ methanol and $10 \%$ acid acetic), filtered and heated three times for $3 \mathrm{~min}$ by microwave; other chemicals.

\subsection{Preparation of Cordyceps extracts}

The cultured biomass and fruit body of C. neovolkiana DL0004 and C. takaomontana DL0038A were dried and extracted in $96 \%$ ethanol $(\mathrm{EtOH})$. The remain of residues was extracted by hot water extraction and precipitated in $96 \%$ ethanol (CPS). Then, those EtOH extracts were fractured by petroleum ether (PE), ethyl acetate (EtOAc), n-butanol (BU) and water (W) fractions in ascending order of polarity by liquid-liquid. The culture of biomasses was dried and extracted in $96 \%$ ethanol (EPS). The extracts were preserved at $-20^{\circ} \mathrm{C}$.

\subsection{Gelatinolytic assay}

At first, $5 \mu \mathrm{L}$ of $0.1 \mathrm{mg} / \mathrm{mL}$ MMP and $10 \mu \mathrm{L}$ of Cordyceps extracts $(2000 \mu \mathrm{g} / \mathrm{mL}$, $200 \mu \mathrm{g} / \mathrm{mL}, 20 \mu \mathrm{g} / \mathrm{mL}$ ) were added into each well and incubated at $37^{\circ} \mathrm{C}$ for an hour. Next, each well was added $10 \mu \mathrm{L}$ of $5 \mathrm{mg} / \mathrm{mL}$ gelatin and $75 \mu \mathrm{L}$ collagenase buffer $(50 \mathrm{mM}$ Tris- $\mathrm{HCl}, 10 \mathrm{mM}$ $\mathrm{CaCl}_{2}, 0.15 \mathrm{M} \mathrm{NaCl}, \mathrm{pH} 7.4$ ) and shaken by hand. The plate was then incubated at $37^{\circ} \mathrm{C}$ for 4 hours. Subsequently, the amount of gelatin remaining was quantified by the addition of the heated $0.2 \%$ coomassie brilliant blue R250 (CBB) $100 \mu \mathrm{L}$. The supernatant was discarded and $250 \mu \mathrm{L}$ of $20 \%$ (v/v) Dimethyl Sulfoxide (DMSO) was added to dissolve the pellet. The plate was finally read for the absorbance at $600 \mathrm{~nm}$. All experiments were carried out in triplicates. Data were processed and analyzed using statistical software.

MMP inhibition activity was determined by the formula [( $\mathrm{A}_{600}$ of the sample - $\mathrm{A}_{600}$ of blank) - $\left(\mathrm{A}_{600}\right.$ of control - $\mathrm{A}_{600}$ of blank)]/ ( $\mathrm{A}_{600}$ of gelatin - $\mathrm{A}_{600}$ of blank) $\times 100$ (Maslin, Kittisak, \& Siriwadee, 2013). Where $\mathrm{A}_{600}$ of the sample was the absorbance value of the sample tested with extract $(2000 \mu \mathrm{g} / \mathrm{mL}, 200 \mu \mathrm{g} / \mathrm{mL}, 20 \mu \mathrm{g} / \mathrm{ml}), \mathrm{A}_{600}$ of the control was the absorbance value of the sample without extracts, $\mathrm{A}_{600}$ of gelatin was the absorbance value of total gelatin, and $\mathrm{A}_{600}$ of the blank was the absorbance of the well containing only CBB and DMSO.

\section{Results}

Cordyceps extracts. Fruit body of C. neovolkiana DL0004 has received 6 extracts (EtOH, PE, EtOAc BU, W, and CPS) and Biomass of C. neovolkiana DL0004 has been received 7 extracts (EtOH, PE, BU, W, CPS, and EPS), in which EPS was collected from the culture 
broth of biomass, Similar to the fruit body and biomass of C. takaomontana DL0038A. Thus, from the fruit body and biomass of C.neovolkiana DL0004 and C. takaomontana DL0038A have been received 26 extracts and using them to MMP inhibition assay.

\subsection{Effect of MMP inhibition activity of biomass and fruit body C. neovolkiana DL0004 extracts}

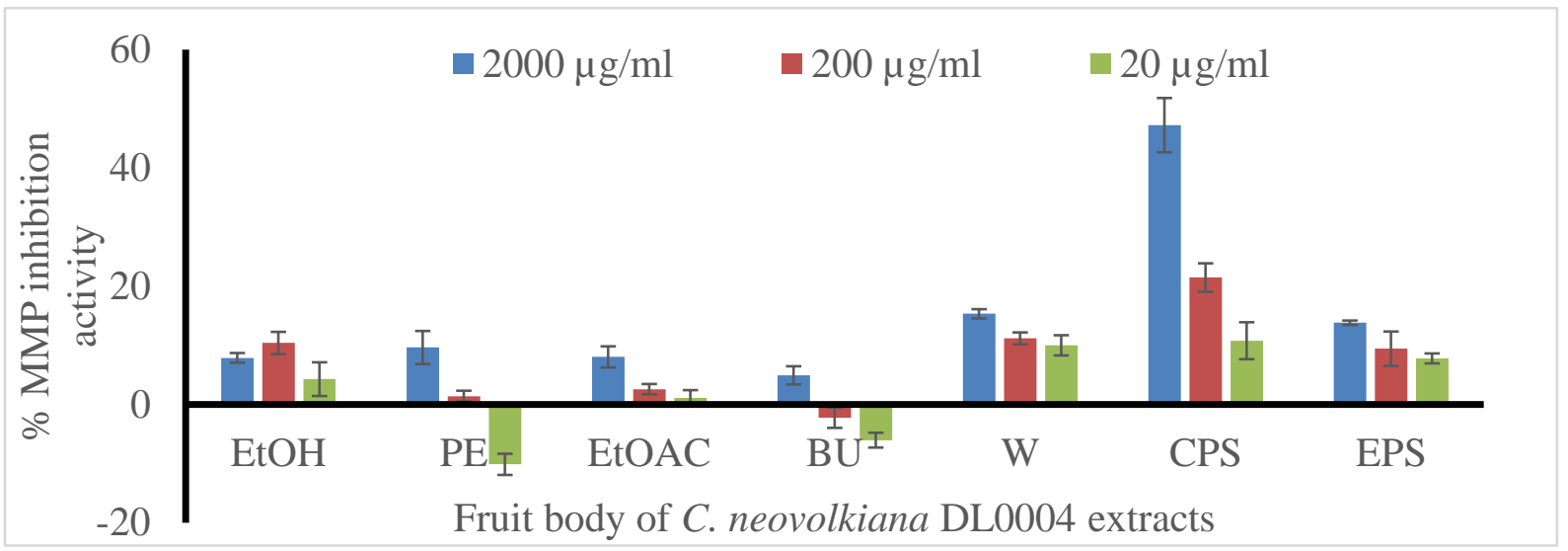

Figure 1. Effect of MMP inhibition activity of fruit body of C. neovolkiana DL0004 extracts

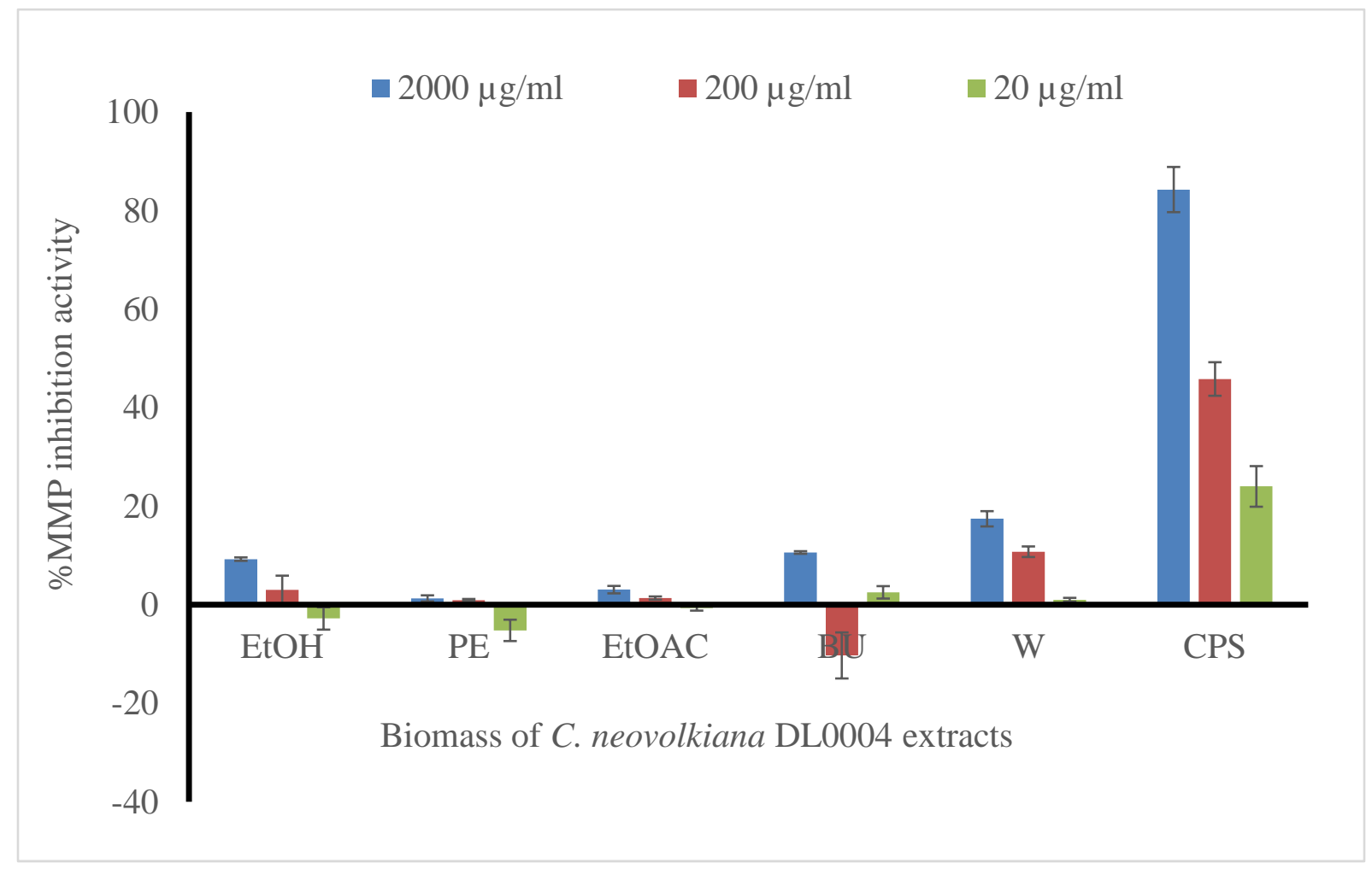

Figure 2. Effect of MMP inhibition activity of biomass of C. neovolkiana DL0004 extracts

Screening for MMP inhibition assay by concentration ranges of $2000 \mu \mathrm{g} / \mathrm{mL}, 200 \mu \mathrm{g} / \mathrm{mL}$, and $20 \mu \mathrm{g} / \mathrm{mL}$ of fruit bodies and biomasses of C. neovolkiana DL0004 (Figure 1 and 2). The results have shown that almost of extracts obtained from $C$. neovolkiana DL0004 have the best MMP inhibition activity at $2000 \mu \mathrm{g} / \mathrm{mL}$; their activity tendency has been reduced or inactivated 
at $200 \mu \mathrm{g} / \mathrm{mL}$ and $20 \mu \mathrm{g} / \mathrm{mL}$. Especially, CPS fruit body has the highest MMP inhibition activity which is $84.27 \% \pm 4.59$ at $2000 \mu \mathrm{g} / \mathrm{mL}$, decreased its activity which is $45.82 \% \pm 3.41$ at $200 \mu \mathrm{g} / \mathrm{mL}$, and finally at $20 \mu \mathrm{g} / \mathrm{mL}$ percent of MMP inhibition is only $24.01 \% \pm 4.12$; While PE fruit body has the lowest MMP inhibition activity which is $1.28 \% \pm 0.62$ at $2000 \mu \mathrm{g} / \mathrm{mL}$. The results for the biomass of $C$. neovolkiana DL0004, at $2000 \mu \mathrm{g} / \mathrm{mL} \mathrm{CPS}$ also have the highest MMP inhibition which is $47.24 \% \pm 4.59$ and BU has the lowest inhibition with rate to $4.93 \% \pm$ 1.54. Thus, looking at figure 1 and figure 2 almost all of the low-polarization (EtOH, PE, EtOAc, and BU) have MMP inhibition activity are lower than the good polarization (W, CPS). In particular, CPSs have been the best ability to inhibit MMP.

With a potential result of the CPS fruit body of $C$. neovolkiana DL0004, continuing to test the ranges of concentrations of $100 \mu \mathrm{g} / \mathrm{mL}, 200 \mathrm{~g} / \mathrm{mL}, 400 \mu \mathrm{g} / \mathrm{mL}, 800 \mu \mathrm{g} / \mathrm{mL}$, and $1600 \mu \mathrm{g} / \mathrm{mL}$ (Figure 3). The $\mathrm{IC}_{50}$ value interpolated from equation $\mathrm{y}=0.0207 \mathrm{x}+41.993$ with $\mathrm{R}^{2}=0.9833$, so determining the $\mathrm{IC}_{50}$ value of CPS fruit body of $C$. neovolkiana DL0004 is $0.39 \mathrm{mg} / \mathrm{mL}$.

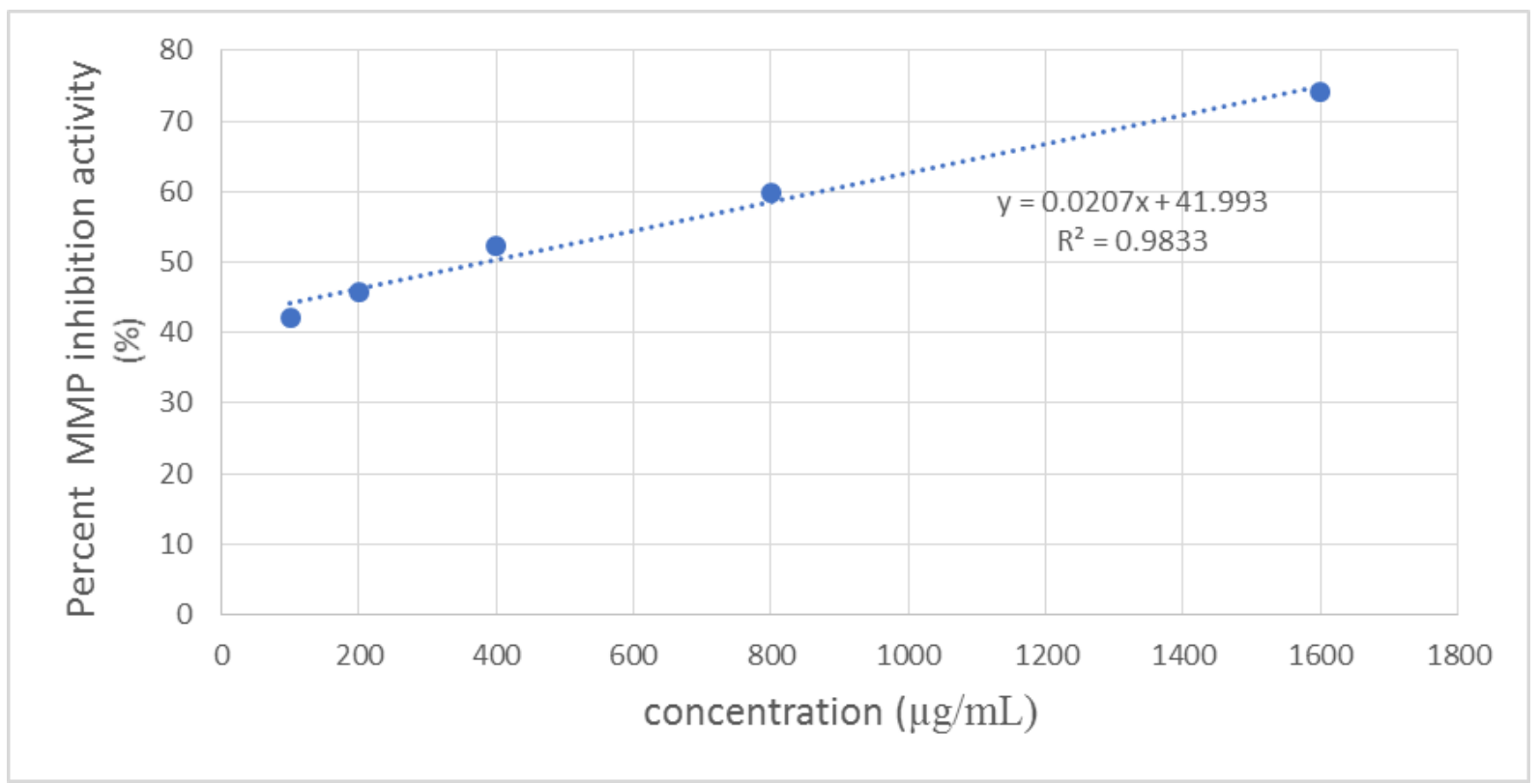

Figure 3. Percent MMP inhibition activity by CPS extract from fruit body of C. neovolkiana DL0004 


\subsection{Effect of MMP inhibition activity of biomass and fruit body C. takaomontakna} DL0038A extracts

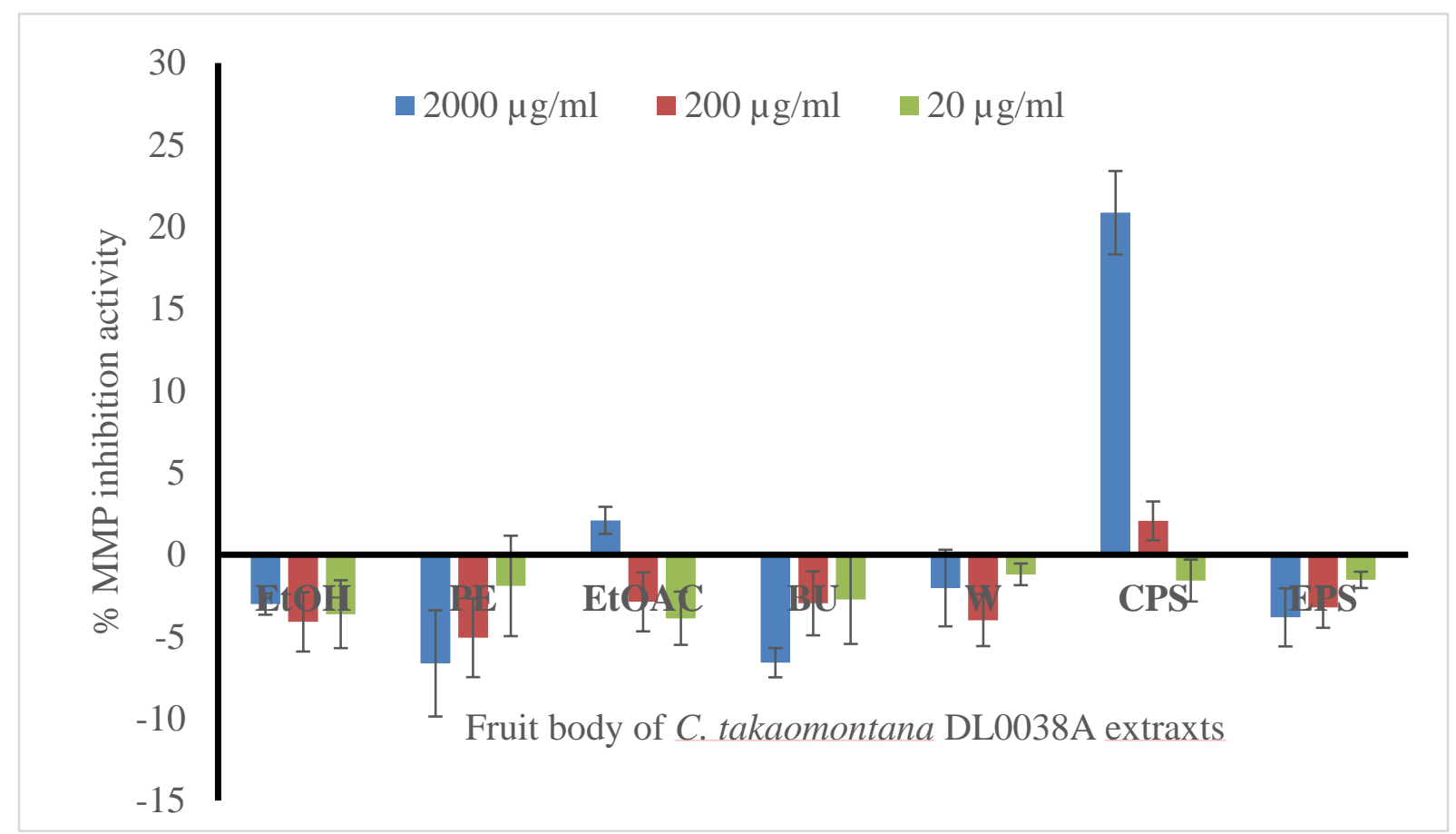

Figure 4. Effect of MMP inhibition activity of fruit body of C.takaomontana DL0038A extracts

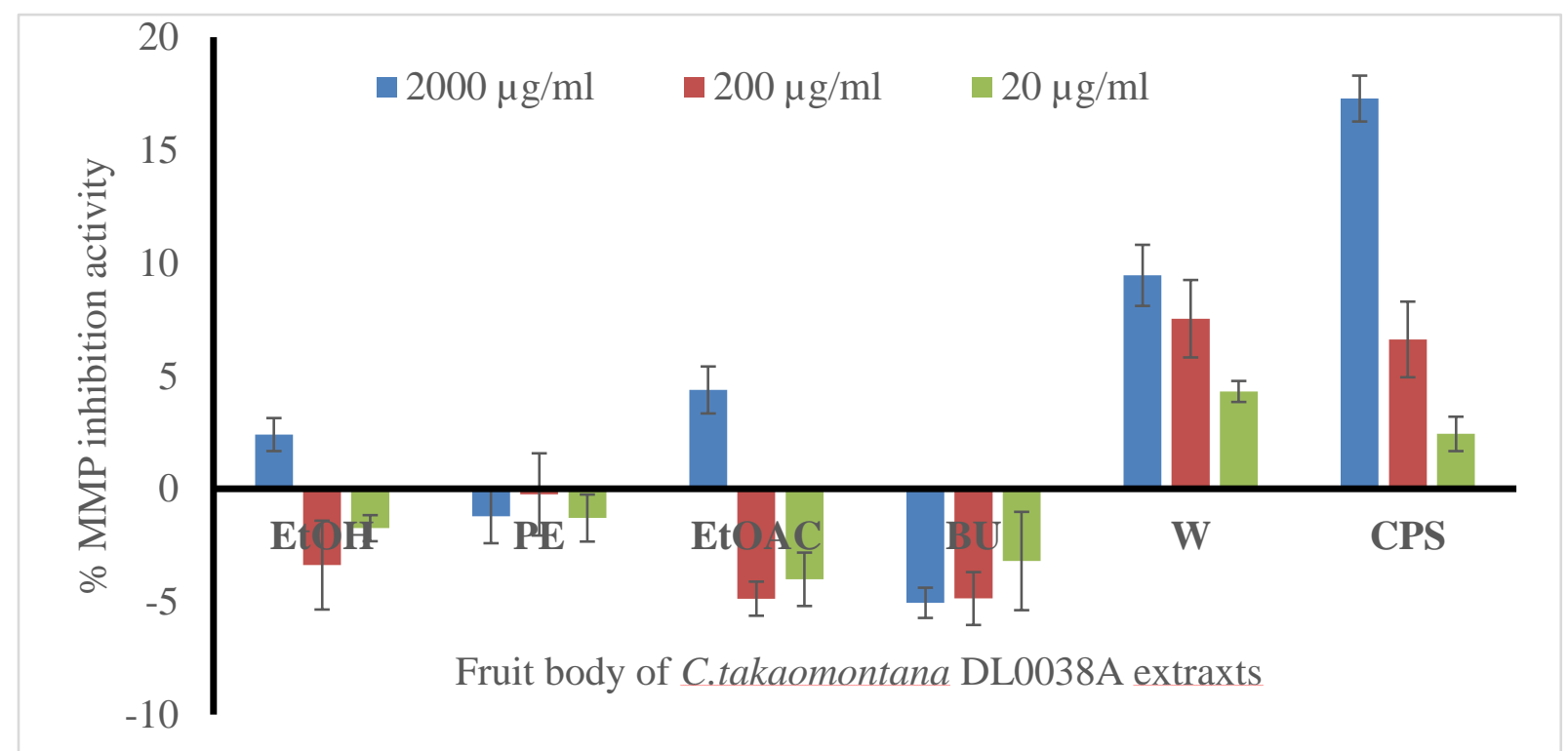

Figure 5. Effect of MMP inhibition activity of biomass of C.takaomontana DL0038A extracts

Figures 4 and 5 have shown that most of the biomass and fruit body of C. takaomontana DL0038A have almost no MMP inhibitory activity. In which, at $2000 \mu \mathrm{g} / \mathrm{mL}$ CPS of biomass has MMP inhibition activity is $20.86 \% \pm 2.55$, insignificantly higher than CPS of fruit bodies 
(17.28\% \pm 1.02$)$. However, when compared with C. neovolkiana DL0004, percent MMP inhibiton activity of CPS of fruit bodies is lower than the CPS of biomass C. neovolkiana DL004 is 1.78 times and lower than the CPS of fruit body C. neovolkiana is 4.87 times. Thus, it can be seen that the MMP inhibition activity of CPS has been different between biomass and fruit body, and the difference between different strains.

Almost of researches on MMP inhibition activity of Cordyceps mainly focused on inhibiting MMP biosynthesis in cancer cell lines. C. militaris grown on germinated soybeans, extract of fruit body was determined to decrease the level of MMP-3 and -9 mRNA and p53 protein in its treated RAW264.7 (Park \& Park, 2013) or polysaccharide from C. sinensis could anti-liver fibrosis are probably associated with the inhibitor HSC activation, TGF- $\beta 1 / \mathrm{Smad}$ signaling pathway, as well as MMP-2, MMP-9 activity and TIMP2 expression (Peng, Li, Feng, Chen, $\mathrm{Xu}, \& \mathrm{Hu}, 2013)$. While to research on Cordyceps strains collected and cultured in Vietnam for anti-metastasis activities are not much, the results have determined that CPS has the best MMP inhibition activity which tends to be similar to the study of Peng et al. (2013), because CPS is a polysaccharide obtained from Cordyceps which is one of the components with the high molecular weight and biological activity in anti-tumor, stimulating the immune system and the ability to reduce blood sugar, oxidation, anti-inflammatory (Russell \& Paterson, 2008), so this study result has continued to determine potentially the effect of polysaccharide on inhibiting MMP biosynthesis on some cancer cell lines.

\section{Conclusion}

This result showed that some C. neovolkiana DL0004 and C. takaomontana DL0038A extracts can inhibit MMP activity. In which, CPS extract of the C. neovolkiana DL0004 fruit body is the highest one on inhibition of MMP with $84.27 \% \pm 4.59$ at $2000 \mu \mathrm{g} / \mathrm{mL}$. The result is the basis for further studies on inhibiting MMP biosynthesis in cancer cell lines.

\section{ACKNOWLEDGMENTS}

The authors thank Dr. Truong for providing the source of C. neovolkiana DL0004 and C. takaomontana DL0038A and Institute of Tropical Biology supported equipment for this study.

\section{References}

Chau, I., Rigg, A., \& Cunningham, D. (2003). Matrix metalloproteinase inhibitor-an emphasis on gastrointestinal malignancies. Critical Reviews in Oncology/Hematology, 45(2), 151176.

Dinh, M. H., Lao, D. T., Vu, T. L., Trinh, V. H., Le, A. T. H., \& Truong, B. N. (2017). Discovery of entomopathogenic fungi Cordyceps takaomontana at Langbian mountain, Lam Dong, Vietnam. Journal of Science and Technology, 55(1A), 19-26.

Gialeli, C., Theocharis. D., \& Karamanos, K. N. (2010). Roles of matrix metalloproteinases in cancer progression and their pharmacological targeting. The FEBS Journal, 278(1), 1627. 
Ha, J. W., Yoo, H. S., Shin, J. W., Cho, J. H., Lee, N. H., Yoon, D. H., .. Cho, C. K. (2006). Effects of Cordyceps militaris extract on tumor immunity. Korean Journal of Oriental Medicine, 27(4), 12-29.

Hubbell, H. R., Requignot, E. C., Willis, D. H., Lee C., \& Suhadolnik, R. J. (1985). Differential antiproliferactive actions of 2,5 oligo a trimer core and its cordycepin analogue on human tumor cells. International Journal of Cancer, 36(3), 389-394.

Le, L. T. T., Pham, H. N. K., Do, L. T. T., Le, T. H. A., Dinh, H. M., \& Truong, N. B. (2010). Discovering the entomopathogenic fungus Cordyceps neovolkiana from Langbian mountain, Da Lat City, Vietnam. Journal of Biotechnology, 8(3A), 1007-1013.

Lee, H. L., Lee, S., Lee, K., Shin, Y. S., Kang, H., \& Cho, H. (2015). Anti-cancer effect of Cordyceps militaris in human colorectal carcinoma RKO cells via cell cycle arrest and mitochondrial apoptosis. DARU Journal of Pharmaceutical Sciences, 23(1), 35-43.

Maslin, O., Kittisak, B., \& Siriwadee, C. (2013). A modified colorimetric method of gelatinolytic assay using bacteroal collagenase type II as a model. Analytical Biochemistry, 433(2), 168-170. doi:10.1016/j.ab.2012.09.036

Nguyen, K. P. P. (2007). Method of isolation of organic compounds. In Publisher Vietnam National University Ho Chi Minh City (pp. 28-36).

Park, D. K., \& Park, H. J. (2013). Ethanol extract of cordyceps militaris grown on germinated soybeans attenuates Dextran-Sodium-Sulfate-(DSS-) induced colitis by suppressing the expression of matrix metalloproteinases and inflammatory mediators. BioMed Research International, 2013, 1-10. doi:10.1155/2013/102918

Peng, J., Li X., Feng, Q., Chen, L., Xu, L., \& Hu, Y. (2013). Anti-fibrotic effect of Cordyceps sinensis polysaccharide: Inhibitor HSC activation, TGF- $\beta 1 / \mathrm{Smad}$ signalling, MMPs and TIMs. Experimental Biology and Medicine, 238(6), 668-770.

Rahul, J., \& Kent, H. (2012). Metastatic cancer: Integrated organ system and biological approach. In Landes bioscience (pp. 2-25).

Robert, V., \& Hideaki, N. (2003). Matrix metalloproteinases ang tissue inhibitors of metalloproteinases: Structure, function and biochemistry. Circulation Research, 92(8), 827-839.

Russell, R., \& Paterson, M. (2008). Cordyceps a traditional Chinese medicine and another fugal therapeutic biofactory. In Phytochemistry (pp. 1469-1495). 